Be Connected є системою онлайн послуг, яка допомагае літнім австрахійцям здобуті цифрову грамотність та покращити навички користування. Ресурс пропонуе курси користування базовими електронними пристроями та роботи в мережі Інтернет.

У результаті проведеного дослідження було зроблено висновок, щзо освітні послуги для людей похилого віку в Австралї̈ надаються багатьма урядовими та неурядовими організаціями, які допомагають літнім хюдям продовжувати залишатися активними учасниками суспільного життя.

Наукова новизна роботи полягае в наданні огляду на основні освітні послуги та програми для ^юдей похилого віку в Австралї̈, визначенні важливості постійної освіти в похилому віцзі та висвітленні освітньої складової інших послуг для цุих людей.

Ключові слова: освітні послуги в Австралії, надання послуг, послуги для людей похилого siky.

Дата надходження статті: 17.01.2020 p. Рецензент: доктор педагогічних наук, професор Калашник $\Lambda$. С.

УДК 378.011.3 - 051:364.4:005.963.2

DOI https://doi.org/10.37915/pa.vi45.69

Курант O. $\epsilon_{.}^{*}$, orcid.org/0000-0003-4741-414X

\title{
ОСОБЛИВОСТІ ФОРМУВАННЯ ГОТОВНОСТІ МАЙБУТНІХ СОЦІАЯЬНИХ ПРАЦІВНИКІВ ДО ПРОФЕСІЙНОЇ ДІЯЯЬНОСТІ ЗАСОБАМИ КОУЧИНГУ
}

У статті розглянуто питання використання сучасних інноваційних засобів формування готовності в процесі освітньої діяльності здобувачів вищої освіти напряму «соціальна робота». Визначено, що коучинг мае певні переваги на фоні класичних засобів навчання, оскільки складається з особливих взаємин між викладачем і студентом; характеризується ефективно організованим процессом пошуку кращцих відповідей на широке коло запитань, щзо є значимим у контексті особистісного та професійного росту; надає орієнтири у визначенні напряму розвитку; сприяе сфокусуванню та утриманню уваги й полегшуе сприйняття; ціікавість процесу забезпечуе системність роботи, а отже, і системність у професійних заняттях Майбутні спеціалісти мають змогу креативно, в атмосфері взаемної довіри, изілеспрямованого альянсу та ініціативної амбітної готовності, генерувати та втілювати свої ідеї, включатися в живий інтерактивний розвивальний процес, формулювати бажаний результат, визначати акмеологічні бар'єри, які заважають досягати визначеної професійної мети, знайти потенційні ресурси для досягнення результату, вибудовувати систему підтримки професійних ініціатив, відслідковувати результати, глибще пізнати свої здібності, зрозуліти, яким способом найефективніше втілити поставлені цһілі.

При проведенні освітнвого професійного коучингу науковці рекомендують дотримуватися трьох положень: робота з переконаннями, ицінностями та иілями. У статті наведено приклад програми професійного коучингу для формування готовності майбутніх соціальних працівників. Запропонована методика удосконалення управлінської та комунікативної компетентності майбутніх соцзільних працівників, на нашу думку, єдостатньо продуктивною, оскільки підвищуе мотивацію $і$ таким чином забезпечуе формування професійних навичок; сприяе розумінню та розвитку своїх можливостей, розвиває навички глибокого осмислення социільних проблем, зумовлюе ефективну та успішну професійну реалізаціюо.

Ключові слова: готовність, коучинг, професійний коучинг, соціальна робота.

*C) Курант O. 6 .

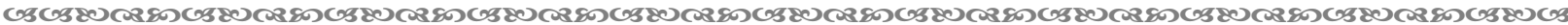
185 
Постановка проблеми. 3 огляду на сучасні соціально-економічні умови в Україні значно підвищуються вимоги до професійних якостей фахівців різних галузей в цілому, і соціальних працівників зокрема. Фахівці соціальної сфери мають володіти високим рівнем професіоналізму, мати високий інтелектуальний, творчий потенціал, ефективно та оперативно виконувати свої посадові обов' язки, мати сформовані професійнозначущі особистісні якості, професійно саморозвиватися, самовдосконалюватися тощо.

На сьогодні в Україні підготовка фахівців соціальної сфери грунтується на концепції, згідно з якою навчання здобувачів освіти відображає соціальний розвиток, сприяе активному пошуку шляхів вирішення нагальних соціальних проблем. Професіонали соціальної сфери мають бути готові коригувати, усунути та трансформувати негативні соціальні прояви в суспільстві.

Одним із важдивих завдань ЗВО є формування та розвиток інтелектуального потенціалу майбутніх фахівців, що визначатиме в майбутньому ефективність виконання професійних завдань на високому рівні. Сучасний спеціаліст повинен стратегічно мислити, уміти вчасно зорієнтуватися, бути здатним ситуативно реагувати на нові професійні виклики. Специфіка діяльності соціального працівника вимагає професійної гуманістичної світоглядної життєвої позиції, високої емоційної культури, комунікативної компетентності, здатності до самоаналізу, самовідновлення, рефлексії, динамічного розвитку здібностей, стійкої сформованості професійно значущих інтелектуально-особистісних якостей тощо. Вищезазначені вимоги визначаються специфікою праці: соціальна підтримка, соціальний захист, обслуговування та надання допомоги кризовим категоріям клієнтів. Оскільки професійна діяльність характеризується напруженням, затратою сил, то саме засоби коучингу виступають тим інструментом, що дозволяють особистості якісно, раціонально та ефективно розпоряджатися власними ресурсами. А формування готовності до професійної діяльності засобами коучингу е одним із ключових завдань сучасної вищої освіти [5].

Аналіз досліджень. Питання професійної підготовки особистості посідає центральне місце серед сучасних наукових досліджень. Цю проблему аналізують у контексті оновленого соціального замовлення, що вимагає від фахівця високої конкурентоспроможності, стресостійкості, гнучкості, відмінного здоров'я, зацікавленості в продуктивній професійній діяльності. Саме це завдання має вирішувати професійна підготовка майбутніх соціальних працівників, поєднуючи в собі накопичений досвід та сучасні інноваційні підходи.

Заслуговують на особливу увагу праці, у яких висвітлюеться питання модернізації освітнього процесу у вищій школі (В. Кремень, В. Лозова, О. Попова, І. Прокопенко, С. Сисоєва, О. Сухомдинська), теорії і методики професійної підготовки майбутніх соціальних працівників (С. Архипова, М. Галагузова, А. Капська, В. Поліщук, Л. Тюптя та ін.); педагогічного забезпечення формування професійних якостей майбутніх соціальних працівників (Н. Зобенко, І. Мельничук та ін.), професійної підготовки майбутніх соціальних працівників в умовах університетської освіти (О. Карпенко). Проблема дослідження готовності особистості до професійної діяльності розглянута в роботах С. Архангельського, Ю. Бабанського, Т. Коваль, А. Конаха, Н. Аогутіної, О. Макаренко, О. Семеног та ін. Деякі аспекти становлення соціального працівника як професіонала розкриті в наукових дослідженнях В. Поліщук.

Дослідженням засобів коучингу займаються такі закордонні науковці: М. Аткінсон, Т. Голві, А. Грант, К. Грифінта, М. Дауні, Е. Паролод, Дж. Роджерс, Б. Соуза, Дж. Уітмор та ін. У контексті освіти над проблемою працювали такі вітчизняні та зарубіжні дослідники і науковці: А. Браун, Т. Голві, Дж. Джеймсон, М. Доуней, К. Дуглас, Р. Еверд, П. Зеус, Р. Кілбург, К. Колетт, Дж. О'Коннор, А. Дейджес, Т. Деонард, К. Мак-Каулей, Д. Пітерсон, Дж. Селмен, Е. Тач, Д. Вітворт, Дж. Вітмор, Т. Шуелл, І. Голіяд, О. Комар, О. Пометун, С. Романова, В. Сідоренко, О. Тіщук, Т. Чернова та ін. Досдідженням

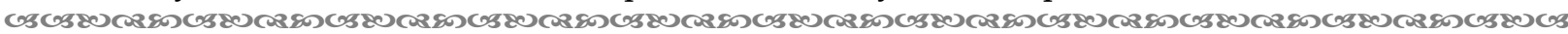
186 
коучингу в професійній освіті в Україні здійснили С. Романова, Т. Борова, О. Нежинська, В. Тименко.

Попри численні доробки сучасних учених, відкритими залишаються питання саме підготовки майбутніх соціальних працівників до професійної діяльності засобами коучингу.

Метою статті є висвітлення особливостей формування готовності майбутніх соціальних працівників до професійної діяльності засобами коучингу.

Виклад основного матеріалу. Питання формування готовності здобувачів вищої освіти до професійної діяльності засобами коучингу є відносно новим у науковій літературі, відповідно серед дослідників ще не сформувалось однозначної думки щодо цього питання.

Поняття «готовність» досить часто вживається в науковій дітературі як психологічний стан чи установка. В. Савіцька зазначає, що трактування «готовності до професійної діяльності» має декілька підходів:

- функціональний, за яким готовність вважають психічним станом особистості, що визначає потенційну активізацію психічних функцій під час майбутньої професійної діяльності;

- особистісний, де готовність виступає цілісним особистісним утворенням, що інтегрує сукупність внутрішніх суб'єктивних чинників окремої діяльності та досліджується переважно в контексті професійної підготовки до неї;

- особистісно-діяльний, у межах якого готовність окреслюеться як прояв усіх граней особистості, які забезпечують можливість ефективно виконувати професійні функції;

- результативно-діяльнісний, що визначає готовність як результат процесу підготовки [6].

Ми розглядаємо професійну підготовку як процес здобуття кваліфікації за відповідним напрямом підготовки. Професійна підготовка фахівця соціальної сфери в умовах ЗВО визначається засвоєнням системи знань, сформованістю професійних умінь і навичок, що забезпечуе усвідомлення професійної діяльності. Вона базуеться на кваліфікаційних вимогах, що поєднують у собі сукупність професійних вимог, характеристик, показників, цінностей, ролей, функцій тощо.

У сучасних соціально-економічних умовах до змісту професійної готовності фахівця соціальної сфери висувається низка нових вимог, серед яких кдючове місце займає вміння застосовувати свої знання і вміння для соціальної допомоги окремим особам, сім'ям, групам, організаціям, громадам, соціуму загалом [4]. Соціальні працівники мають бути готовими підвищувати здатність клієнтів виходити самостійно 3 кризових життєвих ситуацій, створювати необхідні для цього умови та надавати ресурси, забезпечуючи взаємодію між июдьми або між людиною та ії оточенням, налагоджувати комунікацію між клієнтом та установами соціального спрямування, підвищувати відповідальність організацій за клієнта, впливати на соціальну політику. Ефективно виконувати ці завдання здатні добре підготовлені, професійно компетентні працівники.

Аналіз наукової літератури, Галузевого стандарту підготовки здобувачів вищої освіти за напрямом «Соціальна робота» дозволяе зробити висновок про те, що фахівець соціальної сфери має володіти професійними знаннями, бути переконаним у їхній соціальній доцільності й корисності; уміти ефективно застосовувати їх у своїй професійній діяльності; систематично працювати над оновленням професійних знань із соціальної роботи, які формуються із всебічних і глибоких знань професійноорієнтованих та спеціальних дисциплін; бути впевненим у цих знаннях у процесі провадження своєї діяльності; уміти використовувати повний арсенал засобів і прийомів під час вирішення будь-яких питань професійної діяльності. Отже, професійна компетентність соціального працівника - це єдність теоретичної

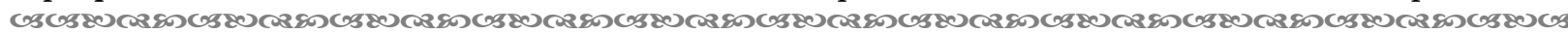


і практичної готовності та здатності випускника закладу вищої освіти кваліфіковано вести професійну діяльність. Це поняття розкривається через сукупність професійних умінь, реалізація яких забезпечуе відповідний їм рівень результативності діяльності фахівця в процесі вирішення професійних завдань [6].

Як показуе аналіз актуальних емпіричних досліджень [там само], показники професійного інтелекту (соціального, емоційного, внутрішньо особистісного тощо) у здобувачів вищої освіти знаходяться переважно на середньому рівні вираженості, що не $є$ сприятливим фактором розвитку та ефективного формування професійної готовності до виконання специфічних професійних завдань. 3 огляду на це в процесі підготовки майбутніх соціальних працівників необхідним є забезпечення системи соціально-психологічних та психолого-педагогічних умов становлення та розвитку професійної готовності: створення професійно орієнтованого середовища, конструктивна навчальна професійна взаємодія, моделювання змісту освіти шияхом поєднання знань та системи практичних умінь та навичок, стимулювання особистісного та інтелектуального потенціалу, підвищувати вміння самокерування, здатність самоорганізації, стимудювати роботу людини на собою в межах як професійного, так і особистісного розвитку, оволодіння методами ділової активності, управління власними ресурсами, тобто вміння їх набувати, зберігати, розвивати, раціонально їх використовувати, бути успішною, незалежною, самодостатньою дюдиною тощо. Важливим сучасним інноваційним інструментом втілення вищезазначених умов у системі професійної підготовки фахівців соціального профілю є професійний коучинг.

Категорія коучингу (від англ. Coaching - тренерство) бере свої витоки у спортивному тренерстві, розроблялася в межах когнітивної, позитивної та організаційної психологї̈, психології управління, консультативної психології тощо. В основі сутності поняття лежать ідеї постійного розвитку природних потенційних можливостей дюдини в різних сферах іiі життедіяльності. У сучасних дослідженнях коучинг висвітдюється в контексті консультування 3 особистісних та професійних проблем [7], як система ефективних трансформаційних комунікацій з самим собою та іншими людьми, як метод управдіння персоналом та технологія активізації потенціалу июдини, засіб «активації» найкращого в людині чи команді [3], як система психологічних прийомів для удосконалення професійної діяльності клієнта чи організації в цілому [5], засіб оптимізації людського потенціалу, професійного становлення та ефективності роботи організації [1] тощо. Поняття коучинг трактується як метод та технологія консультування, що спрямований на розвиток та реалізацію особистісного потенціалу клієнта або групи клієнтів, що має на меті реалізацію максимально можливого ефективного результату в житті загалом або в певній сфері.

Методики коучингу допомагають людині визначити особисті цілі й детальні етапи їх досягнення, підвищити власну самостійність і відповідальність, швидко знаходити правильні рішення складних ситуацій; раціонально витрачати свої ресурси; використовувати власний потенціал тощо. У зв'язку з європейським вектором розвитку української вищої школи, що спрямований на розкриття максимального потенціалу людини, коучинг набуває широкого використання як новий метод навчання самоначання студентів. Його реалізація дає можливість підвищити якість освіти за рахунок розвитку самостійності, творчості, ініціативності та відповідальності студентів.

Як зазначають Л. Музичко та О. Бородієнко, коучинг є виявом особливих взаємин між фахівцем і клієнтом. Сутність цих стосунків у тому, що коуч ефективно організовує процес пошуку клієнтом кращих відповідей на широке коло запитань, що його цікавлять. Коуч допомагає кдієнту розвиватися, виробляти нові вміння й досягати високих результатів у своїй діяльності і закладае кдючові посили до успішного виконання поставлених завдань. Він сприяе вдосконаленню й максимально ефективному використанню особистісних якостей, про які більшість 3 них або

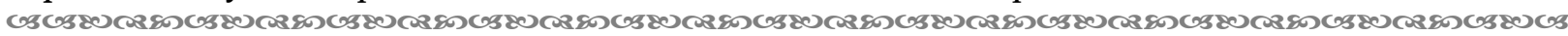
188 
не здогадується, або 3 різних причин не використовує у якості підгрунтя для руху вперед. Також йдеться про стимулювання клієнта до більш гдибокого усвідомлення власних цілей, ресурсів і обмежень, а також допомогу у визначенні напряму розвитку особистості загалом і професійного розвитку зокрема [5].

У контексті використання професійного коучингу як технології формування професійної готовності майбутніх соціальних працівників в освітньому процесі 3ВО ми виділяємо такі його особливості:

- коучинг є засобом підтримки в процесі професійного навчання, спрямований більшим чином на дію, ніж на пояснення чи надання інформації;

- коучинг стимулює розвиток професійно-особистісних якостей;

- коучинг здійснюе оптимізацію процесів адаптації та підвищує мотивацію фахівця ефективніше реалізуватися в професії, сприяе формуванню комфортного для продуктивної праці соціально-психологічного клімату;

- коучинг мотивуе до професійного самопізнання, самоанахізу, саморозуміння, професійної рефлексії та самореалізації, самоактуалізації тощо;

- коучинг підвищуе професійний контродь та самоефективність.

Застосування цієї технології в системі професійної підготовки майбутніх соціальних працівників розширюе ефективні способи та максимально можливі перспективи формування та розвитку професійної готовності, що в подальшому призведе до якісної зміни професійної діяльності фахівців.

Результати досліджень дозволяють нам визначити навчальну програму для формування та розвитку професійної готовності майбутніх соціальних працівників. Освітній професійний коучинг ми розгдядаємо як систему психолого-педагогічних та соціально-педагогічних процесів, що мають на меті формування та розвиток професійної готовності, фахових знань, навичок та умінь у процесі професійного навчання. Навчальна програма призначена для здобувачів вищої освіти, що проходили навчальну та виробничу практику в закладах соціального захисту, соціальних службах тощо, мають власний досвід практичної професійної діяльності в соціальній сфері. Робота передбачає індивідуальні та групові форми взаємодії через активне навчання та зворотній зв'язок. Освітній професійний коучинг зорієнтований на майбутню професійну діяльність та має на меті розвиток професійних інтелектуальноособистісних ресурсів майбутніх соціальних працівників, розвиток їхнього професійного мислення, самоконтролю, самомотивації, професійної мотивації, підвищення професійної реалізації, самостійності, орієнтований на самокоучинг професійного розвитку (управління собою, своїми ресурсами, розкриття потенціалу для досягнення поставлених цілей). Програма сформована так, що дозволяе в процесі коуч-сесій актуалізувати теоретичні знання майбутніх соціальних працівників i, спираючись на їхній досвід, максимально точно змоделювати вектор власної професійної реалізації.

Оволодіння майбутніми фахівцями соціальної сфери засобами коучингу дозводить їм систематично й послідовно здійснювати роботу, спрямовану на самовдосконалення особистісних якостей, розвиток творчого потенціалу, а також не лише успішно вирішувати низку питань особистого характеру, а й дасть змогу успішно організовувати професійну діяльність, що якісно вплине на підвищення ефективності професійної діяльності, тому питання підготовки до професійної діяльності засобами коучингу має стати ключовим у підготовці фахівців діяльності вищої шкоди, адже управлінська компетенція займае одне 3 провідних місць у структурі готовності до фахової діяльності майбутніх соціальних працівників, бо специфіка цієї професії вимагає від спеціаліста вміння бути організатором життєдіяльності своїх кдієнтів, готувати їх до самостійного життя після подолання кризи.

Під час реалізації процесу освітнього професійного коучингу використовуються такі основні техніки: постановка запитань (інтерв'ю), дискусії, мозковий штурм, метод us 189 
конкретних ситуацій, метод емоційного стимулювання, методи створення сприятдивої психодогічної атмосфери, метод створення ситуації пізнавальної дискусії, метод проєктування та моделювання, «письмове есе-розмірковування», рефреймінг, інтерпретації, прояснення, перспективна гра, стратегії результативної творчості, метафори тощо [7; 3].

Технологія проведення освітнього професійного коучингу базується на трьох положеннях коуч-процедур будь-якого типу: переконання, цінності та цілі. В основі роботи - 4 стадії (С. Дуглас, У. Морлей): визначення цілей, оцінювання, планування діяльності, безпосередньо діяльність та моніторинг. Оцінювання ефективності коучингової діяльності здійснюеться на основі оцінки коучингових умінь: відкрита комунікація, колективна робота, неоднорідність робочого середовища (ситуативність, адаптація) тощо [8].

Спираючись на теоретико-практичні дослідження [там само], нами розроблено програму професійного коучингу для розвитку професійної компетентності майбутніх соціальних працівників, що містить п'ять модулів. Наведемо орієнтовний тематичний план коуч-сесій:

1. «Вступ». Коуч-компетентність передбачає інформування клієнта щодо змісту роботи, застосування специфічних інструментів та засобів, визначення принципів роботи, особливостей взаємодії 3 клієнтом, двосторонні права та обов'язки в процесі взаємодії, самостійна робота клієнта між сесіями. По завершенню вступної сесії результатами роботи є визначення мети, завдань роботи, адміністративні питання (графік роботи та ін.), знайомство клієнта і коуча, чітке формулювання запиту та очікування учасників [7].

2. «Розвиток потенціалу професійного мислення та професійної інтуїції в професійній діяльності соціального працівника». Окреслення змісту професійного мислення та професійної компетентності, поточної ситуації (актуального кола проблем, завдань) в професійній діяльності; визначення внутрішніх і зовнішніх перешкод, ризиків на шляху до бажаної цілі; аналіз ресурсів та можливостей для досягнення запланованого результату, вибір конкретного варіанту дій, складання плану та окреслення способів його реалізації, безпосередне виконання запланованого, аналіз результативності та визначення можливих перспектив у вирішенні проблемної ситуації.

3. «Професійна компетентність у соціальній роботі: ефективна співпраця 3 клієнтами». Визначення змісту поняття «професійна компетентність»; діагностика особливостей розвитку, усвідомлення власних резудьтатів роботи та труднощів у професійній діяльності, розвиток емпатичних навичок та навичок впливу в професійній взаємодії з клієнтами; розвиток адаптивних мождивостей та здатності до управління стресовими ситуаціями в професійній взаємодії, розвиток і закріплення позитивного досвіду.

4. «Ефективна

самоорганізація

июдини».

Визначення

змісту внутрішньоособистісних якостей професійної компетентності, що визначає здатність до самореалізації, самомотивації, самоконтролю, саморегуляції, уміння управляти власним потенціалом та внутрішніми ресурсами, систематично стимулювати оптимальні робочі стани: аналіз проблемних ситуацій та труднощів самоорганізації особистості в процесі професійної діяльності, ефективність ухвалення рішень, визначення ключових пріоритетів, розвиток та закріплення здатності самоконтродю, саморегуляції в професійній взаємодії, активізація самодисципліни фахівця, професійна рефлексія.

5. «Самокоучинг ефективності в діяльності соціального працівника». Аналіз змісту професійної мотивації, труднощів та проблему професійній діяльності, мотивації та результативності, професійної відповідальності, самоефективності, рефлексії професійних досягнень, пододання особистих та професійних бар'єрів та обмежень, розвитку професійної самоефективності.

usus80 190 
6. «Рефлексивний аналіз». Співставлення реалізації очікувань та результатів, аналіз задоволеності від процесу коучингу, рефлексія отриманого на сесіях досвіду, осмислення власного потенціалу, ресурсів для втілення максимально продуктивної професійної діяльності, закріплення особистого вектора активної професійної діяльності.

Отже, освітній професійний коучинг є важливим засобом формування професійної готовності майбутніх соціальних працівників, адже забезпечує глибокий розвиток професійнозначущих інтелектуально-особистісних якостей та творчого потенціалу, сприяє розвитку розуміння себе як суб'єкта майбутньої професійної діяльності, формуе потребу в професійному самовдосконаленні. Коуч-технологія в процесі професійної підготовки майбутніх соціальних працівників забезпечує краще розуміння фактичної ситуації, що підвищуе відсоток здатності до успішного вирішення соціальних проблем та якісно підвищує рівень взаємодії з різними групами клієнтів, що підвищуе мотивацію та продуктивність здійснення професійної діядьності і в майбутньому.

Висновки. Аналіз наукової літератури дозволяе робити висновок про те, що професіоналізм фахівця соціальної сфери включає здатність аналізувати ситуацію, правильно іï сприймати, брати до уваги всі існуючі варіанти розвитку соціальної проблеми та робити необхідний вибір; уміння встановлювати контакт 3 клієнтами, здійснювати диференційований підхід; здатність управляти діяльністю соціальної служби, використовувати в соціальної роботі технології проєктування, моделювання тощо. Динамізм сучасних суспільних перетворень викликає потребу у професійнокомпетентних фахівцях соціальної сфери, які вміють аналізувати постійні зміни соціально-економічної тенденції, приймати й реалізовувати нестандартні рішення в ситуації ринкової конкуренції в залежності від специфіки професійної діядьності, усувати стереотипізацію в соціальних відносинах задля розширення своєї гуманістичної спрямованості виробничої й особистісної сфери взаємодії. Формування готовності майбутніх соціальних працівників є важливим завданням сучасної професійної підготовки. Потужним засобом формування професійної готовності в умовах навчання в ЗВО фахівців вищезазначеного напряму $є$ застосування коучингової технології. Особливістю впровадження освітнього професійного коучингу вважаємо забезпечення формування професійно-значущих та особистісних якостей, сприяння розвитку професійного мислення, соціального інтелекту, формування стійких навичок самомотивації, самоконтролю, саморегуляції та саморефлексії в комунікативній професійній взаємодії, забезпечення здатності до об'єктивної оцінки, систематичного моніторингу проблемної ситуації та ухвалення ефективних рішень для вирішення професійних завдань, формування професійної культури, активізація продуктивної творчої діяльності, формує та закріплюе навички самокоучингу тощо.

Освітній професійний коучинг майбутніх соціальних працівників розкривається як система соціальних, психолого-педагогічних умов і впливів, які сприяють розумінню та розвитку своїх можливостей, що за умов дієвої мотивації зумовить ефективну та успішну професійну реалізацію. Розроблена програма освітнього професійного коучингу має структуру, що включає процес формування коучингових умінь та змістові елементи поняття «професійна готовність майбутніх соціальних працівників».

У подальшій перспективі дослідження напряму заплановано гдибше вивчити окремі аспекти ефективності результатів упровадження освітньої програми професійного коучингу під час підготовки майбутніх соціальних працівників.

\section{Список використаних джерел:}

1. Аткинсон М., Рае Т. Чойс. Пошаговая система коучинга. Киев, 2009. 256 с.

2. Державний галузевий стандарт спеціальності «Соціальна робота» / керівник колективу проф. В. П. Бех, А. Й. Капська. Київ, 2005. 273 с. 
3. Дауни М. Эффективный коучинг. Уроки тренера коучей. Москва, 2015. 288 с.

4. Про вищу освіту: Закон України від 1 липня 2014 року No 1556-VII. URL: https://zakon.rada.gov.ua/laws/show/1556-18.

5. Петровська І. Підвищення ефективності управлінської діядьності керівника за допомогою коучингу. Науковий вісник НИТу України. 2010. № 20.14 $\quad$ С. 158-161. URL: http://ipp.lp.edu.ua/WebRC/issues/Issue\%204/Pertovska.pdf.

6. Рябокінь $\lambda$. Професійна компетентність соціальних працівників, як основна умова готовності студентів до професійної діяльності. Гуманітарний вісник дВНЗ «Переяслав-Хмельницький державний педагогічний університет імені Григорія Сковороди»: зб. наукових праць. ПереяславХмельницький, 2010. Вип. 19. С. 226-230.

7. Уитворт Л., Кимси-Хаус Г., Сэндал Ф. Коактивный коучинг (Co-Active-Coaching). Москва, 2004. 360 c.

\section{References:}

1. Atkinson, M., \& Rae, T. Chois. (2009). Poshagovaja sistema kouchinga [Step-by-step coaching system]. Kyiv [in Russian].

2. Bekh, V. P., \& Kapska, A. Y. (2005). Derzhavnyi haluzevyi standart spetsialnosti "Sotsialna robota" [State industry standard of specialty Social work]. Kyiv [in Ukrainian].

3. Dauni, M. (2015). Jeffektivnyj kouching. Uroki trenera kouchej [Effective coaching. Coach Lessons]. Moscow [in Russian].

4. About higher education. No 1556-VII. (2014). Retrieved from https://zakon.rada.gov.ua/laws/show/1556-18 [in Ukrainian].

5. Petrovska, I. (2010). Pidvyshchennia efektyvnosti upravlinskoi diialnosti kerivnyka za dopomohoiu kouchynhu [Improving the effectiveness of managerial management through coaching]. Naukovyi visnyk NLTU Ukrainy Scientific, 20.14, 158-161. Retrieved from http://ipp.lp.edu.ua/WebRC/issues/Issue\%204/Pertovska.pdf [in Ukrainian].

6. Riabokin, L. (2010). Profesiina kompetentnist sotsialnykh pratsivnykiv, yak osnovna umova hotovnosti studentiv do profesiinoi diialnosti [Professional competence of social workers as the main condition for students' readiness for professional activity]. Humanitarnyi visnyk DVNZ "Pereiaslav-Khmelnytskyi derzhavnyi pedahohichnyi universytet imeni Hryhoriia Skovorody", 226-230 [in Ukrainian].

7. Whitworth, L., Kimsey House, G., \& Sandal, F. (2004). Koaktivnyj kouching [Co-Active-Coaching]. Moscow [in Russian].

Kurant O. Y., orcid.org/0000-0003-4741-414X

\section{FEATURES OF FORMATION OF READYNESS OF FUTURE SOCIAL WORKERS FOR PROFESSIONAL ACTIVITY BY MEANS OF COACHING}

The article considers the use of modern innovative means of forming readiness in the process of educational activities of higher education students in the field of "social work". It is determined that coaching has certain advantages against the background of classical teaching aids, as it consists of a special relationship between teacher and student; characterized by an effectively organized process of finding the best answers to a wide range of questions that are important in the context of personal and professional growth; provides guidelines in determining the direction of development; promotes focus and retention of attention and facilitates perception; The interest of the process ensures the system of work, and hence the system in professional classes. Future specialists have the opportunity to creatively, in an atmosphere of mutual trust, purposeful alliance and initiative and ambitious readiness acmeological barriers that prevent the achievement of a certain professional goal, find potential resources to achieve results, build a system of support for professional initiatives, track results, learn more about their abilities, understand how to most effectively implement the goals.

When conducting educational professional coaching, scientists recommend adhering to three provisions: work with beliefs, values and goals. The article gives an example of a professional coaching program for the formation of readiness of future social workers. The proposed method of improving the managerial and communicative competence of future social workers, in our opinion, is quite productive, 
as it increases motivation and thus ensures the formation of professional skills; contributes to the understanding and development of their capabilities, develops skills of deep understanding of social problems, determines the effective and successful professional realization.

Key words: readiness, coaching, press coaching, social work.

Дата надходження статті: 15.01.2020 p. Рецензент: доктор педагогічних наук, професор Міщик И. I. 